Bull. Chem. Soc. Ethiop. 2020, 34(3), 543-556.

ISSN 1011-3924

(C) 2020 Chemical Society of Ethiopia and The Authors

Printed in Ethiopia

DOI: https://dx.doi.org/10.4314/bcse.v34i3.10

\title{
SYNTHESIS, STRUCTURAL ELUCIDATION AND ELECTROCHEMICAL BEHAVIOR OF SOME OXIME-PHENYLALANINE MIXED LIGAND COMPLEXES
}

\author{
Ufuk Türkay Öztoprak ${ }^{1}$, Sabriye Perçin Özkorucuklu ${ }^{2}$, Gizem Yildirim Baştemur ${ }^{3}$, Mukadder \\ Erdem Tunçmen ${ }^{4}$ and Fatma Karipcin ${ }^{5 *}$ \\ ${ }^{1}$ Nevşehir Hacı Bektaş Veli University, Chemistry Department, Nevşehir, Turkey \\ ${ }^{2}$ Istanbul University, Science Faculty, Department of Molecular Biology and Genetics, İstanbul, \\ Turkey \\ ${ }^{3}$ Istanbul University, Institute of Graduate Studies in Sciences, Programme of Molecular \\ Biology and Genetics, İstanbul, Turkey \\ ${ }^{4}$ Süleyman Demirel University, Innovative Technologies Application and Research Center, \\ Isparta, Turkey \\ ${ }^{5}$ Nevşehir Hacı Bektaş Veli University, Chemistry Department, Nevşehir, Turkey
}

(Received March 20, 2020; Revised November 3, 2020; Accepted November 17, 2020)

\begin{abstract}
Four new mixed ligand complexes Me(II)/phenylalanine (phe)/HL [HL =4-(4-bromophenylaminoisonitrosoacetyl)biphenyl and $\mathrm{Me}=\mathrm{Co}, \mathrm{Ni}, \mathrm{Cu}, \mathrm{Zn}$ ] were synthesized. These complexes are formulated as: $\left[\mathrm{CoL}(\right.$ phe $\left.)\left(\mathrm{H}_{2} \mathrm{O}\right)_{2}\right],\left[\mathrm{NiL}(\mathrm{phe})\left(\mathrm{H}_{2} \mathrm{O}\right)_{2}\right],\left[\mathrm{CuL}(\mathrm{phe})\left(\mathrm{H}_{2} \mathrm{O}\right)_{2}\right]$ and $\left[\mathrm{ZnL}(\mathrm{phe})\left(\mathrm{H}_{2} \mathrm{O}\right)_{2}\right]$. All the compounds were characterized by elemental analyses, FT-IR, magnetic susceptibility measurements, TG/DTA and cyclic voltammetry $(\mathrm{CV})$ experiments. IR spectral data confirmed the coordination of the oxime ligand to the metal ions through the oxime and carbonyl oxygen. The geometrical structures of the complexes have been found to be octahedral. The measured molar conductance values of the complexes in DMF are in agreement with the nonelectrolytic nature ofthe complexes. The elemental analyses confirm a 1:1:1 [metal:HL:L(phenylalanine)] molar ratio. Thermal behavior of the compound was investigated by thermal gravimetric analysis (TG) and differential thermal analysis (DTA) techniques. All the complexes were transformed into metal oxides after thermal degradation. The electrochemical properties of both ligand and their complexes were analyzed by cyclic voltammetry $(\mathrm{CV})$ using glassy carbon electrode in DMF solution containing $0.1 \mathrm{M}$ TBAP as supporting electrolyte.
\end{abstract}

KEY WORDS: Oxime, electrochemical characterization, mixed ligand complexes, amino acid, phenylalanine

\section{INTRODUCTION}

Oximes are noteworthy complexing agents due to the several electron-rich donor centers with unusual structural and chemical properties and they can form different types of coordination compounds with transition metal ions [1-4]. Oxime based ligands and their transition metal complexes are potential analytical, spectrophotometric and bioactive agents [4-9]. A huge body of literature is available on the chemical synthesis of oximes, oxime complexes and their applications [1-9].

Among the numerous organic ligands that have been employed for the formation of metallic complexes, amino acids consist a very important family of ligands, due to their versatility regarding the coordination mode and binding properties towards metal ions [10]. Amino acids are present in all living organisms, which are essential for various biochemical processes that ensure the permanence of life in the individuals, can act as potential oxygen and nitrogen donor ligands, too $[11,12]$. Under biological conditions, amino acids bind to transition metal ions via the carboxylate- $\mathrm{O}$ and the amino-N donor atoms, thereby forming a thermodynamically stable five-membered chelate ring $[13,14]$. The amino acid complexes with biologically active metal

*Corresponding author. E-mail: fkaripcin@nevsehir.edu.tr

This work is licensed under the Creative Commons Attribution 4.0 International License 
ions have received much attention because they proved to be useful antibacterial agents, nutritive supplies for humans and animals, and also as models for metalloproteins [11-17].

L-Phenylalanine, containing non-polar phenyl group, is a common aromatic amino acid in living organisms. It is essential to cross the blood-brain barrier, changes into tyrosine in vivo and makes essential hormones, such as norepinephrine and epinephrine. The derivatives of phenylalanine are important in pharmaceutical field, e.g. in the case of Parkinson's drug L-3,4dihydroxyphenylalanine (L-DOPA) [12, 14, 18].

The ligand quantity, ligand type, and coordination geometry have important factors on the biological activity and the other properties of metal-based complexes. In recent years, the formation and properties of mixed ligand complexes have received much attention because they can provide new materials with useful properties such as biological activity [14-20], electrical conductivity [21] and photoluminescence [22].

Many mixed amino acid complexes have considerable biological activity, such as antitumor properties, and usually increase the diffusibility of complexes and enhance their biological action inside the cell. Such systems are widely used in the field of chemotherapy [12, 14, 23]. The introduction of amino acid co-ligands such as phenylalanine might affect the planarity, hydrophobicity, and coordination geometry of synthesized complexes [17]. On the basis of stated facts, we have decided to prepare and characterize mixed ligand transition metal [Co(II), $\mathrm{Ni}(\mathrm{II}), \mathrm{Cu}(\mathrm{II}), \mathrm{Zn}(\mathrm{II})]$ complexes derived from 4-(4-bromophenylamino-isonitrosoacetyl)biphenyl (HL) as primary ligand and phenylalanine (phe) as coligands. The complexes prepared were characterized particularly by elemental analysis, molar conductance, magnetic moment and FT-IR. The relative thermal stabilities of the complexes and their electrochemical behavior have also been discussed.

\section{EXPERIMENTAL}

\section{Materials and measurements}

All chemicals used were of reagent grade. All chemicals were purchased from Merck or Aldrich and were used as received. Melting points of all the compounds determined on EZ-Melt Automated Melting Point Apparatus in open glass capillaries. Elemental (C, H, N) analyses were carried out by standard methods with a LECO, CHNS-932 analyzer. The IR spectra of the compounds were recorded on a Perkin Elmer Spectrum 100 FT-IR instrument with the samples in 4000-600 $\mathrm{cm}^{-1}$ range. The molar conductivity measurements $\left(\Lambda_{\mathrm{m}}\right)$ were taken in dimethylformamide (DMF) at $25{ }^{\circ} \mathrm{C}$, using concentrations of $1.0 \times 10^{-3} \mathrm{M}$ for the complexes. Thermal analyses (TG/DTA) were recorded on Shimadzu TG DTA 60 thermal analyzer with a heating rate of $10 \mathrm{~K} / \mathrm{min}$ in dynamic $\mathrm{N}_{2}$ atmosphere. ${ }^{1} \mathrm{H}$ NMR and ${ }^{13} \mathrm{C}$ NMR spectra were recorded on a Bruker Avance III $400 \mathrm{MHz}$ FT-NMR. The proposed molecular structure of mixed ligand complexes are given in Figure 1.

\section{Cyclic voltammetry measurements}

Electrochemical measurements were conducted using an Autolab Potentiostat/Galvanostat PGSTAT-302N device controlled by Nova 2.1.4 program on a computer. A standard three electrode electrochemical cell was used for all measurements and main parts of this cell are a glassy carbon (GCE) as working electrode (2.0 mm diameter), platinum wire as counter electrode, and a $\mathrm{Ag} / \mathrm{AgCl}$ as reference electrode. Previous to each experiment, GCE was polished with 1.0, 0.3 and $0.05 \mu \mathrm{m}$ alumina powder. Residual alumina particles were removed by an ultrasonic bath. Afterwards, the electrode was dried and washed with pure DMF before use. Cyclic voltammetry studies were performed in DMF containing $0.1 \mathrm{M}$ tetrabutylammonium perchlorate (TBAP) as supporting electrolyte with an analyte concentration of $2.0 \mathrm{mM}$. All solutions were purged with nitrogen for $10 \mathrm{~min}$ before measurements, and the experiments were carried out at room temperature. 


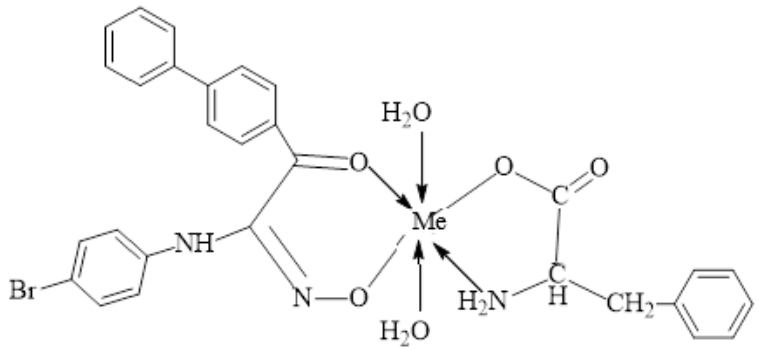

Figure 1. Proposed molecular structure of the mixed ligand complexes.

\section{Synthesis}

Synthesis of ligand (HL). 4-(4-Bromophenylaminoisonitrosoacetyl)biphenyl (HL) was prepared according to previously published procedures $[3,4]$. First, 4-biphenylhydroximoyl chloride $(1.5$ mmol; $0.389 \mathrm{~g})$ were dissolved in $\mathrm{EtOH}(50 \mathrm{~mL})$ and the mixture was cooled $0{ }^{\circ} \mathrm{C}$. Then $4-$ bromoaniline $(3 \mathrm{mmol}, 0.51 \mathrm{~g})$ in $\mathrm{EtOH}(10 \mathrm{~mL})$ was added dropwise to solution of first solution over $15 \mathrm{~min}$ with cooling. After that period, the reaction mixture was stirred $1 \mathrm{~h}$ at the same temperature. Then it was allowed to stir at ambient temperature for $2 \mathrm{~h}$ and diluted $100 \mathrm{~mL}$ distilled water. The resulting precipitate was filtered and then recrystallized from ethanol. The product was filtered off, washed distilled water, cold ethanol and dried on $\mathrm{P}_{2} \mathrm{O}_{5}$. The synthetic route of the ligand is shown in Scheme 1.

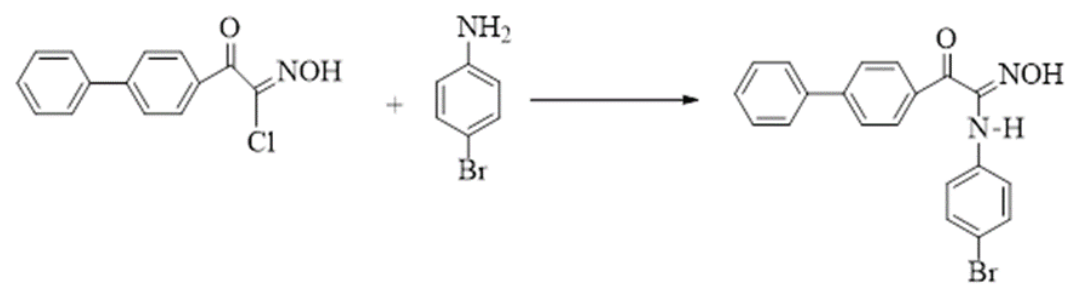

HL

Scheme 1. Synthesis of proposed ligand HL.

L. Yellow; yield: $90.5 \%$; mp: $160{ }^{\circ} \mathrm{C}$; mol wt: 395.23 ; elem. anal. calcd: $\mathrm{C}, 60.78 ; \mathrm{H}, 3.82 ; \mathrm{N}$, 7.09\%. Found: C, 61.17; H, 3.83; N, 7.17\%; FT-IR $\left(\mathrm{cm}^{-1}\right): 3425 \mathrm{~m}(\mathrm{O}-\mathrm{H}), 3034 \mathrm{w}, 738 \mathrm{~s}, 655 \mathrm{~m}$ $(\mathrm{C}-\mathrm{H})_{\mathrm{Ar}}, 2917 \mathrm{w}(\mathrm{C}-\mathrm{H})_{\mathrm{Al}}, 1667 \mathrm{~s}(\mathrm{C}=\mathrm{O})$ and $v_{\mathrm{as}}\left(\mathrm{COO}^{-}\right), 1586 \mathrm{~s}(\mathrm{C}=\mathrm{N}), 1402 \mathrm{~m}(\mathrm{C}=\mathrm{C})_{\mathrm{Ar}}, 1215 \mathrm{~m}$ (C-N), $1172 \mathrm{~m}(\mathrm{C}-\mathrm{C}), 1052 \mathrm{~s}(\mathrm{~N}-\mathrm{O}) ;{ }^{1} \mathrm{H}-\mathrm{NMR}\left(\mathrm{CDCl}_{3}\right): \mathrm{N}-\mathrm{OH}(\mathrm{s}, 1 \mathrm{H}) 10.86 \mathrm{ppm} ; \operatorname{Ar}(\mathrm{C}-\mathrm{H})(\mathrm{m}$, $13 \mathrm{H}) 7.32-8.12 \mathrm{ppm} ; \mathrm{N}-\mathrm{H}(\mathrm{s}, 1 \mathrm{H}) 6.76 \mathrm{ppm} .{ }^{13} \mathrm{C} \mathrm{NMR}\left(\mathrm{CDCl}_{3}, \mathrm{ppm}\right): 183(\mathrm{C}=\mathrm{O}) ; 147$ $(\mathrm{C}=\mathrm{NOH}) ; 127-139 \mathrm{C}_{\mathrm{Ar}}$.

Synthesis of $\left[\mathrm{CoL}(\right.$ phe $\left.)\left(\mathrm{H}_{2} \mathrm{O}\right)_{2}\right]$ (1). Complex $\mathbf{1}$ was prepared by addition of $\mathrm{Co}\left(\mathrm{CH}_{3} \mathrm{COO}\right)_{2} \cdot 4 \mathrm{H}_{2} \mathrm{O}(1.5 \mathrm{mmol}, 0.37 \mathrm{~g})$ in $50 \mathrm{~mL}$ of ethanol to the ligand $(1.5 \mathrm{mmol}, 0.59 \mathrm{~g})$ in $20 \mathrm{~mL}$ of hot methanol. The resulting mixture was refluxed for $30 \mathrm{~min}$. To this solution, Lphenylalanine ( $1.5 \mathrm{mmol}, 0.24 \mathrm{~g})$ dissolved in $4 \mathrm{~mL}$ water containing $\mathrm{KOH}(1.5 \mathrm{mmol}, 0.24 \mathrm{~g})$ and $10 \mathrm{~mL}$ methanol was added with constant stirring and refluxed for $4 \mathrm{~h}$. On standing, the solid product was collected by filtration, washed several times with cold water, ethanol, anhydrous ether and dried on $\mathrm{P}_{4} \mathrm{O}_{10}$. 
[CoL(phe) $\left.\left(\mathrm{H}_{2} \mathrm{O}\right)_{2}\right]$. Brown; yield: $67.4 \%$; dp: $272{ }^{\circ} \mathrm{C}$; mol wt: 653.35 ; elem. anal. calcd: C, 53.9; $\mathrm{H}, 4.32 ; \mathrm{N}, 6.43 \%$. Found: C, 53.71; H, 4.35; N, 6.29\%; $\Lambda_{\mathrm{M}}\left(\mathrm{DMF}\right.$ solution, $\left.\Omega^{-1} \mathrm{~cm}^{2} \mathrm{~mol}^{-1}\right)$ : 7.2; $\mu_{\text {eff }}$ BM: 1.33. FT-IR $\left(\mathrm{cm}^{-1}\right): 3359 \mathrm{~b}, 834 \mathrm{~m}(\mathrm{O}-\mathrm{H}), 3265 \mathrm{w}(\mathrm{N}-\mathrm{H}), 3029 \mathrm{~s}, 725 \mathrm{~m}, 659 \mathrm{~m}(\mathrm{C}-$ $\mathrm{H})_{\mathrm{Ar}}, 2921 \mathrm{w}(\mathrm{C}-\mathrm{H})_{\mathrm{Al}}, 1653 \mathrm{~m}(\mathrm{C}=\mathrm{O})$ and $\mathrm{v}_{\mathrm{as}}\left(\mathrm{COO}^{-}\right), 1599 \mathrm{~s} \mathrm{C}=\mathrm{N}, 1399 \mathrm{~m}(\mathrm{C}=\mathrm{C})_{\mathrm{Ar}}$ and $\mathrm{v}_{\mathrm{s}}\left(\mathrm{COO}^{-}\right)$ $1261 \mathrm{~m}(\mathrm{C}-\mathrm{O}), 1216 \mathrm{~m}(\mathrm{C}-\mathrm{N}), 1179 \mathrm{~m}(\mathrm{C}-\mathrm{C}), 1046 \mathrm{~m}(\mathrm{~N}-\mathrm{O})$.

Synthesis of $\left[\mathrm{NiL}(\mathrm{phe})\left(\mathrm{H}_{2} \mathrm{O}\right)_{2}\right]$ (2). Complex 2 was prepared by addition of $\mathrm{Ni}\left(\mathrm{CH}_{3} \mathrm{COO}\right)_{2} \cdot 4 \mathrm{H}_{2} \mathrm{O}$ $(1.5 \mathrm{mmol}, 0.37 \mathrm{~g})$ in $50 \mathrm{~mL}$ of ethanol to the ligand $(1.5 \mathrm{mmol}, 0.59 \mathrm{~g})$ in $20 \mathrm{~mL}$ of hot methanol. The resulting mixture was refluxed for $30 \mathrm{~min}$. To this solution, L-phenylalanine (1.5 mmol, $0.24 \mathrm{~g})$ dissolved in $4 \mathrm{~mL}$ water containing $\mathrm{KOH}(1.5 \mathrm{mmol}, 0.24 \mathrm{~g})$ and $10 \mathrm{~mL}$ methanol was added with constant stirring and refluxed for $4 \mathrm{~h}$. On standing, the solid product was collected by filtration, washed several times with cold water, ethanol, anhydrous ether and dried on $\mathrm{P}_{4} \mathrm{O}_{10}$.

[NiL(phe) $\left(\mathrm{H}_{2} \mathrm{O}\right)_{2}$ ]. Light brown; yield: $70.6 \%$; dp: $246^{\circ} \mathrm{C}$; mol wt: 653.12 ; elem. anal. calcd: $\mathrm{C}$, 53.33; H, 4.32; N, 6.43\%. Found: C, 52.86; H, 4.64; N, 6.64\%; $\Lambda_{\mathrm{M}}$ (DMF solution, $\Omega^{-1} \mathrm{~cm}^{2} \mathrm{~mol}^{-1}$ : 4.2; $\mu_{\text {eff }}$ BM: 2,70; FT-IR $\left(\mathrm{cm}^{-1}\right): 3354$ b, $833 \mathrm{~m}(\mathrm{O}-\mathrm{H}), 3290 \mathrm{w}(\mathrm{N}-\mathrm{H}), 3029 \mathrm{~s}, 720 \mathrm{~m}, 668 \mathrm{~s}$ $(\mathrm{C}-\mathrm{H})_{\mathrm{Ar}}, 2958 \mathrm{w}(\mathrm{C}-\mathrm{H})_{\mathrm{Al}}, 1650 \mathrm{~m}(\mathrm{C}=\mathrm{O})$ and $\mathrm{v}_{\mathrm{as}}\left(\mathrm{COO}^{-}\right), 1614 \mathrm{~s}(\mathrm{C}=\mathrm{N}), 1388 \mathrm{~s}(\mathrm{C}=\mathrm{C})_{\mathrm{Ar}}$ and $v_{\mathrm{s}}\left(\mathrm{COO}^{-}\right), 1265 \mathrm{~m}(\mathrm{C}-\mathrm{O}), 1224 \mathrm{~m}(\mathrm{C}-\mathrm{N}), 1160 \mathrm{~m}(\mathrm{C}-\mathrm{C}), 1033 \mathrm{~m}(\mathrm{~N}-\mathrm{O})$.

Synthesis of $\left[\mathrm{CuL}(\mathrm{phe})\left(\mathrm{H}_{2} \mathrm{O}\right)_{2}\right]$ (3). Complex 3 was prepared by addition of $\mathrm{Cu}\left(\mathrm{CH}_{3} \mathrm{COO}\right)_{2} \cdot \mathrm{H}_{2} \mathrm{O}$ $(1.5 \mathrm{mmol}, 0.29 \mathrm{~g})$ in $50 \mathrm{~mL}$ of ethanol to the ligand $(1.5 \mathrm{mmol}, 0.59 \mathrm{~g})$ in $20 \mathrm{~mL}$ of hot methanol. The resulting mixture was refluxed for $30 \mathrm{~min}$. To this solution, L-phenylalanine (1.5 mmol, $0.24 \mathrm{~g})$ dissolved in $4 \mathrm{~mL}$ water containing $\mathrm{KOH}(1.5 \mathrm{mmol}, 0.24 \mathrm{~g})$ and $10 \mathrm{~mL}$ methanol was added with constant stirring and refluxed for $4 \mathrm{~h}$. On standing, the solid product was collected by filtration, washed several times with cold water, ethanol, anhydrous ether and dried on $\mathrm{P}_{4} \mathrm{O}_{10}$.

[CuL (phe) $\left.\left(\mathrm{H}_{2} \mathrm{O}\right)_{2}\right]$. Brown; yield: $62.4 \%$; dp: $223{ }^{\circ} \mathrm{C}$; mol wt: 657.97 ; elem. anal. calcd: C, 52.94; H, 4.29; N, 6.39\%. Found: C, 52.49; H, 4.03; N, 6.78\%; $\Lambda_{\mathrm{M}}\left(\mathrm{DMF}\right.$ solution, $\Omega^{-1} \mathrm{~cm}^{2} \mathrm{~mol}^{-1}$ ): 3.7; $\mu_{\text {eff }}$ BM: 1.75. FT-IR $\left(\mathrm{cm}^{-1}\right): 3332$ b, $838 \mathrm{~s}(\mathrm{O}-\mathrm{H}), 3248 \mathrm{~s}(\mathrm{~N}-\mathrm{H}), 3032 \mathrm{~s}, 719 \mathrm{~m}, 673 \mathrm{~m}$ $(\mathrm{C}-\mathrm{H})_{\mathrm{Ar}}, 2961 \mathrm{w}(\mathrm{C}-\mathrm{H})_{\mathrm{Al}}, 1663 \mathrm{w}(\mathrm{C}=\mathrm{O})$ and $\mathrm{v}_{\mathrm{as}}\left(\mathrm{COO}^{-}\right), 1615 \mathrm{~s}(\mathrm{C}=\mathrm{N}), 1383 \mathrm{~s}(\mathrm{C}=\mathrm{C})_{\mathrm{Ar}}$ and $\mathrm{v}_{\mathrm{s}}\left(\mathrm{COO}^{-}\right), 1273 \mathrm{~m}(\mathrm{C}-\mathrm{O}), 1217 \mathrm{~m}(\mathrm{C}-\mathrm{N}), 1160 \mathrm{~m}(\mathrm{C}-\mathrm{C}), 1033 \mathrm{w}(\mathrm{N}-\mathrm{O})$.

Synthesis of $\left[\mathrm{ZnL}(\right.$ phe $\left.)\left(\mathrm{H}_{2} \mathrm{O}\right)_{2}\right]$ (4). Complex 4 was prepared by addition of $\mathrm{Zn}\left(\mathrm{CH}_{3} \mathrm{COO}\right)_{2} \cdot \mathrm{H}_{2} \mathrm{O}$ $(1.5 \mathrm{mmol}, 0.32 \mathrm{~g})$ in $50 \mathrm{~mL}$ of ethanol to the ligand $(1.5 \mathrm{mmol}, 0.59 \mathrm{~g})$ in $20 \mathrm{~mL}$ of hot methanol. The resulting mixture was refluxed for $30 \mathrm{~min}$. To this solution, L-phenylalanine (1.5 mmol, $0.24 \mathrm{~g})$ dissolved in $4 \mathrm{~mL}$ water containing $\mathrm{KOH}(1.5 \mathrm{mmol}, 0.24 \mathrm{~g})$ and $10 \mathrm{~mL}$ methanol was added with constant stirring and refluxed for $4 \mathrm{~h}$. On standing, the solid product was collected by filtration, washed several times with cold water, ethanol, anhydrous ether and dried on $\mathrm{P}_{4} \mathrm{O}_{10}$.

[ZnL(phe) $\left(\mathrm{H}_{2} \mathrm{O}\right)_{2}$ ] . Light orange; yield: $54.2 \%$; dp: $248{ }^{\circ} \mathrm{C}$; mol wt: 659.81 ; elem. anal. calcd: C, 52.79; H, 4.27; N, 6.37\%. Found: C, 52.58; H, 4.77; N, 6.15\%; $\Lambda_{\mathrm{M}}$ (DMF solution, $\Omega^{-1} \mathrm{~cm}^{2} \mathrm{~mol}^{-1}$ ): 2.3 ; $\mu_{\text {eff }}$ BM: Dia.; FT-IR $\left(\mathrm{cm}^{-1}\right): 3333$ b, $836 \mathrm{~m}(\mathrm{O}-\mathrm{H}), 3255 \mathrm{~s}(\mathrm{~N}-\mathrm{H}), 3029 \mathrm{~m}, 720 \mathrm{~m}, 681 \mathrm{~s}$ $(\mathrm{C}-\mathrm{H})_{\mathrm{Ar}}, 2958 \mathrm{~m}(\mathrm{C}-\mathrm{H})_{\mathrm{Al}}, 1675 \mathrm{w}(\mathrm{C}=\mathrm{O}), 1614 \mathrm{~s}(\mathrm{C}=\mathrm{N}), 1388 \mathrm{~s}(\mathrm{C}=\mathrm{C})_{\mathrm{Ar}}$ and $\mathrm{v}_{\mathrm{s}}\left(\mathrm{COO}^{-}\right), 1265 \mathrm{~m}$ (C-O), $1224 \mathrm{w}(\mathrm{C}-\mathrm{N}), 1160 \mathrm{~m}(\mathrm{C}-\mathrm{C}), 1033 \mathrm{~m}(\mathrm{~N}-\mathrm{O}) .{ }^{1} \mathrm{H}-\mathrm{NMR}\left(\mathrm{CDCl}_{3}\right): \operatorname{Ar}(\mathrm{C}-\mathrm{H})(\mathrm{m}, 13 \mathrm{H}) 7.34-$ 8.23 ppm; N-H (s, 1H, oxime) 7.04 ppm; N-H (s, 1H, phe) 6.21 ppm; $\mathrm{H}_{2} \mathrm{O}$ (coord. s, 4H) 5.82 ppm; $\mathrm{CH}\left(\mathrm{m}, 1 \mathrm{H}\right.$, phe) $4.41 \mathrm{ppm} ; \mathrm{CH}_{2}$ (d, 2H, phe) 4.08 ppm. 


\section{RESULTS AND DISCUSSION}

\section{Microanalyses and molar conductance measurements}

The synthesized ligand and the mixed ligand complexes were investigated using various physiochemical properties like melting point (m.p.), color, yield, micro analytical data and molar conductance value are given in the experimental part. The obtained $\mathrm{C}, \mathrm{H}$, and $\mathrm{N}$ analytical data of the synthesized metal(II) complexes agreed well with the calculated values which confirm a 1:1:1 (metal:HL:L-phenylalanine) molar ratio.

Molar conductivity measurements of the metal complexes were determined using freshly prepared solutions of the complexes in DMF at room temperature.The measured molar conductance values of $10^{-3} \mathrm{M}$ solutions of the mixed ligand complexes werefound to be in the range 2.3-7.2 $\mathrm{S} \mathrm{cm}^{2} \mathrm{~mol}^{-1}$ which is in agreement with the non-electrolytic nature ofthe complexes [17]. The results of the elemental analysis of the mixed ligand complexesare in good agreement with those required by the proposed formula.

$N M R$ spectra of the oxime ligand $(\mathrm{HL})$ and the mixed ligand $\mathrm{Zn}$ complex $\left\{\left[\mathrm{ZnL}(\mathrm{phe})\left(\mathrm{H}_{2} \mathrm{O}\right)_{2}\right]\right\}$

The oxime ligand in $\mathrm{CDCl}_{3}$ was studied by ${ }^{1} \mathrm{H}$ and ${ }^{13} \mathrm{C}$ NMR spectroscopy. The deuteriumexchangeable proton of the $(\mathrm{N}-\mathrm{OH})$ group for the HL showed a chemical shift at $10.86 \mathrm{ppm}$ as a singlet [4]. In the region of 7.32-8.12 ppm, chemical shifts for aromatic hydrogens were assigned as multiplet. The chemical shift of the aromatic amine proton of HL appeared at 6.76 ppm as a singlet. In ${ }^{13} \mathrm{C}$ NMR spectrum, the aromatic carbon resonances were shown in between $\delta=127-139 \mathrm{ppm}$ which is corresponding to the bromophenyl and biphenyl rings in the compound. The carbonyl and oxime carbons were clearly observed at $\delta=183$ and $147 \mathrm{ppm}$, respectively and more slightly deshielded in the spectra. The increasing electronegativity of oxygen and nitrogen atoms and different environment and conformations cause a deshielding effect for these signals. All of these values prove that the oxime ligand formed and are in good agreement with the values previously reported $[4,24,25]$. Since $\mathrm{Co}$ (II), $\mathrm{Ni}$ (II) and $\mathrm{Cu}(\mathrm{II})$ complexes are paramagnetic, their ${ }^{1} \mathrm{H}$ and ${ }^{13} \mathrm{C}$ spectra could not be obtained.

The ${ }^{1} \mathrm{H}$ NMR spectrum of free oxime ligand were compared with the diamagnetic mixed ligand $\mathrm{Zn}(\mathrm{II})$ complex taken in $\mathrm{CDCl}_{3}$ medium. Unfortunately, the insolubility of phenylalanine in $\mathrm{CDCl}_{3}$ makes it difficult to obtain ${ }^{1} \mathrm{H}$ NMR spectrum of phenylalanine to further clarify the binding of phenylalanine ligand to the metal ions. $\mathrm{Zn}$ (II) complex are well established in their predictable regions [26]. The absence of $\mathrm{COOH}$ proton of phe peak in the $\mathrm{Zn}$ (II) complex indicates that this proton is removed during chelation process and this prove that phe ligand is coordinated through bidentate mode with the $\mathrm{Zn}(\mathrm{II})$ ion via amino- $\mathrm{N}$ and deprotonated carboxylato-O atoms [26]. Also, the disappearance of proton peak of $-\mathrm{NOH}$ at $10.86 \mathrm{ppm}$ for $\mathrm{HL}$ in the complex prove that oxime ligand is coordinated through bidentate mode with the $\mathrm{Zn}$ (II) ion via carbonyl and deprotonated oximato-O atoms. In the region of 7.34-8.23 ppm, chemical shifts for aromatic hydrogens were assigned as multiplet. The chemical shifts of the aromatic amine proton of HL and amine proton of phe appeared at 7.04 and $6.21 \mathrm{ppm}$ as a singlet, respectively. In addition, the spectrum of $\mathrm{Zn}$ (II) complex shows a characteristic new peak centered at $5.82 \mathrm{ppm}$, which confirm the presence of coordinated water molecule [17, 27]. The protons of the $\mathrm{CH}$ and $\mathrm{CH}_{2}$ groups for phe in the $\mathrm{Zn}$ (II) complex showed chemical shifts at 4.41 and $4.08 \mathrm{ppm}$. Thus, the NMR studies reinforce the findings drawn from the vibrational spectral studies about the mode of binding.

FTIR spectroscopy

The IR spectra of the investigated complexes (Figure 3) are compared with those of the free ligand (Figure 2) to determine the coordination sites. The basic theory involved is that the 
stretching modes of the ligands change upon complexation due to weaking/strengthening of the bonds involved in the bond formation resulting in subsequent change in the position of the bands appearing in the IR spectrum. The spectrum of the oxime ligand exhibits a characteristic band at $3425 \mathrm{~cm}^{-1}$ due to the stretching vibration of the $\mathrm{OH}$ group. On the other hand, the IR spectra of all the complexes show broad band at 3359-3332 $\mathrm{cm}^{-1}$ which have been assigned to $v(\mathrm{OH})$ stretching vibration of water molecules, in accordance with the results of the elemental analysis listed in Section 2.3 [11, 28-30].

The oxime ligand HL shows strong absorption band at $1667 \mathrm{~cm}^{-1}$ due to $\mathrm{v}(\mathrm{C}=\mathrm{O})$ and 1586 $\mathrm{cm}^{-1}$ due to $v(\mathrm{C}=\mathrm{N})$. The $(\mathrm{C}=\mathrm{N})$ band is shifted to $1615-1599 \mathrm{~cm}^{-1}$ in the complexes indicating the involvement of the nitrogen atom of the azomethine group in the coordination to the metal ion $[11,28-32]$. The $(\mathrm{C}=\mathrm{O})$ band is located in the same region $\left(1675-1650 \mathrm{~cm}^{-1}\right)$ with $v_{\text {as }}\left(\mathrm{COO}^{-}\right)$ stretching bands of amino acidsor disappeared indicating the participation of carbonyl oxygen atom in coordination [26].

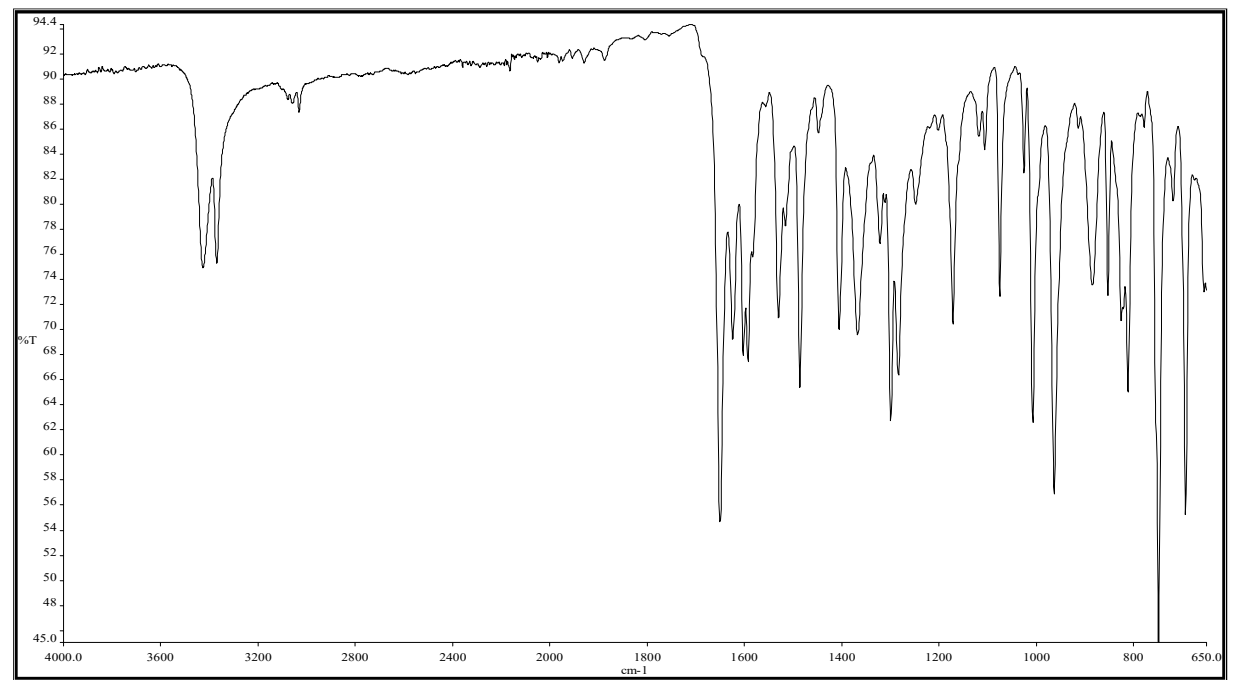

Figure 2. FT-IR spectrum of 4-(4-bromophenylaminoisonitrosoacetyl)biphenyl (HL).

The strong absorption at $1052 \mathrm{~cm}^{-1}$ due to $v(\mathrm{~N}=\mathrm{O})$ of the oxime group in the free HL ligand is shifted towards lower frequency regions $1046-1033 \mathrm{~cm}^{-1}$ in all the complexes [3, 33, 34]. Allthese features indicate that the HL is coordinated to the metal ion through the oxygen of the oxime group.

The $v\left(\mathrm{NH}_{3}{ }^{+}\right)$of free amino acids is observed in the range $2933-3369 \mathrm{~cm}^{-1}$ [11]. In the complexes, $\mathrm{NH}_{3}{ }^{+}$gets deprotonated and binds to metal through the neutral $\mathrm{NH}_{2}$ group. The $\mathrm{NH}_{2}$ symmetric stretching is recorded at $3344 \mathrm{~cm}^{-1}$ in the IR spectrum of free phenylalanine [35]. The IR spectra of complexes show characteristic bands of $v\left(\mathrm{NH}_{2}\right)$ in the region $3290-3248 \mathrm{~cm}^{-1}$ $[11,36]$. The spectra of amino acids display $v_{a s}\left(\mathrm{COO}^{-}\right)$and $v_{s}\left(\mathrm{COO}^{-}\right)$frequency in the 1551$1634 \mathrm{~cm}^{-1}$ and $1379-1420 \mathrm{~cm}^{-1}$ range, respectively. In the metal complexes, $\mathrm{v}_{\mathrm{as}}\left(\mathrm{COO}^{-}\right)$and $v_{s}\left(\mathrm{COO}^{-}\right)$stretching bands are located in the region $1675-1650 \mathrm{~cm}^{-1}$ and $1399-1383 \mathrm{~cm}^{-1}$, respectively $[11,23]$. The ligand L-phenylalanine coordinates with $\mathrm{M}(\mathrm{II})$ ions through amino-N of $\mathrm{NH}_{2}$ group and deprotonated carboxylato- $\mathrm{O}$ of $\mathrm{COOH}$ group to form a stable 5-membered chelate ring $[17,29,30]$. 


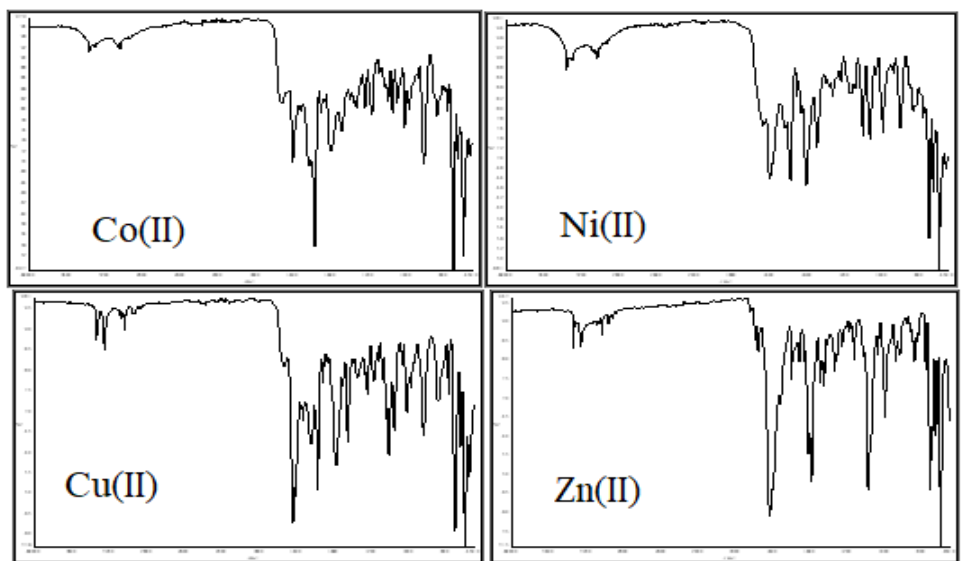

Figure 3. FT-IR spectra of the mixed ligand complexes $\left[\mathrm{MeL}(\mathrm{phe})\left(\mathrm{H}_{2} \mathrm{O}\right)_{2}\right]$.

The infrared spectra of the oxime ligand and the mixed ligand complexes are very much consistent with the structural data presented in this paper and these absorption data are in agreement with those previously reported for similar compounds [23, 28-36]. From this study, both the ligands HL and phe are bidentate which form stable metal chelates through the oxygen of deprotonated oxime group and carbonyl oxygen and amino- $\mathrm{NH}_{2}$ and deprotonated carboxylato-O atoms, respectively.

\section{Magnetic measurements}

In a magnetic field, the paramagnetic compounds will be attracted while the diamagnetic compounds repelled. Therefore, paramagnetic substances will have positive susceptibilities. Thus, the magnetic susceptibility measurements provide information regardingthe geometric structure of the complexes. The room temperature magnetic moment measurements show that the $\mathrm{Zn}(\mathrm{II})$ complex is diamagnetic and are likely to octahedral. The Ni(II) complex is paramagnetic with magnetic susceptibility value of 2.70 B.M., which fits the $\mathrm{d}^{8}$ metal ion in an octahedral structure, the two-spin value of 2.83 B.M. [3, 36]. $\mathrm{Cu}(\mathrm{II})$ and $\mathrm{Co}(\mathrm{II})$ complexes are paramagnetic with magnetic susceptibilities of 1.75 B.M. and 1.33 B.M., respectively. Measured value of the magnetic moment for the cobalt complex, which corresponds to one unpaired electron and falls within the range normally observed for low-spin octahedral $\mathrm{Co}^{2+}$ complexes. $\mathrm{The} \mathrm{Cu}(\mathrm{II})$ complex fits the spin value of 1.73 B.M. indicating an octahedrald ${ }^{9}$-system $[26,33$, 36-38].

\section{Thermal studies}

Thermal analysis (DTA/TG) for themetal complexes was carried out within the temperature range from ambient temperature up to $1000{ }^{\circ} \mathrm{C}$. The correlations between the different decomposition steps of the complexes with the corresponding weight losses are discussed in terms of the proposed formula of the complexes. Initially, first weight losses correspond to the removal of coordinated water molecule. All the complexes (1-4) in the first stage show the weight loss of $5.90-6.40 \%$ within the temperature range $21-238{ }^{\circ} \mathrm{C}$. These weight losses correspond to the removal of water molecule from the complexes [17]. Amino acid ligand, Lphenylalanine moiety elimination occurred the second stage. In the final stage, decomposition of 
primary oxime ligand leading to the formation of MO (metal oxide) as residue [17, 39-43]. DTA/TG profiles of these complexes are given in Figures 4-7.

The $\mathrm{Co}(\mathrm{II})$ complex (1) with the general formula $\left[\mathrm{C}_{29} \mathrm{H}_{28} \mathrm{~N}_{3} \mathrm{O}_{6} \mathrm{BrCo}\right]$ is thermally decomposed in two successive decomposition steps. The first step with estimated mass loss of $6.20 \%$ was found within the temperature range $21-182{ }^{\circ} \mathrm{C}$ and corresponds to loss of two $\mathrm{H}_{2} \mathrm{O}$ molecules (calculated mass loss $=5.51 \%$ ). The second step occurs within the temperature range $182-850{ }^{\circ} \mathrm{C}$ with an estimated mass loss $81.28 \%$ (calculated mass loss $=83.02 \%$ ) are reasonably accounted for the decomposition of the ligand molecules leaving $\mathrm{CoO}$ residue.

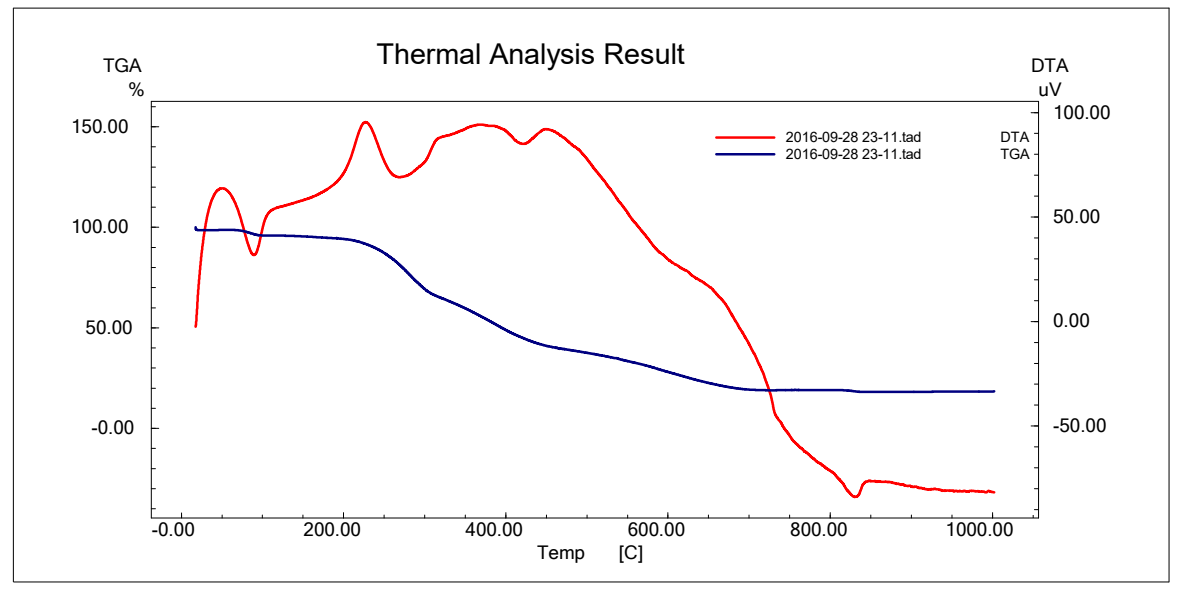

Figure 4. DTA/TG diagram of $\left[\mathrm{CoL}(\mathrm{phe})\left(\mathrm{H}_{2} \mathrm{O}\right)_{2}\right]$.

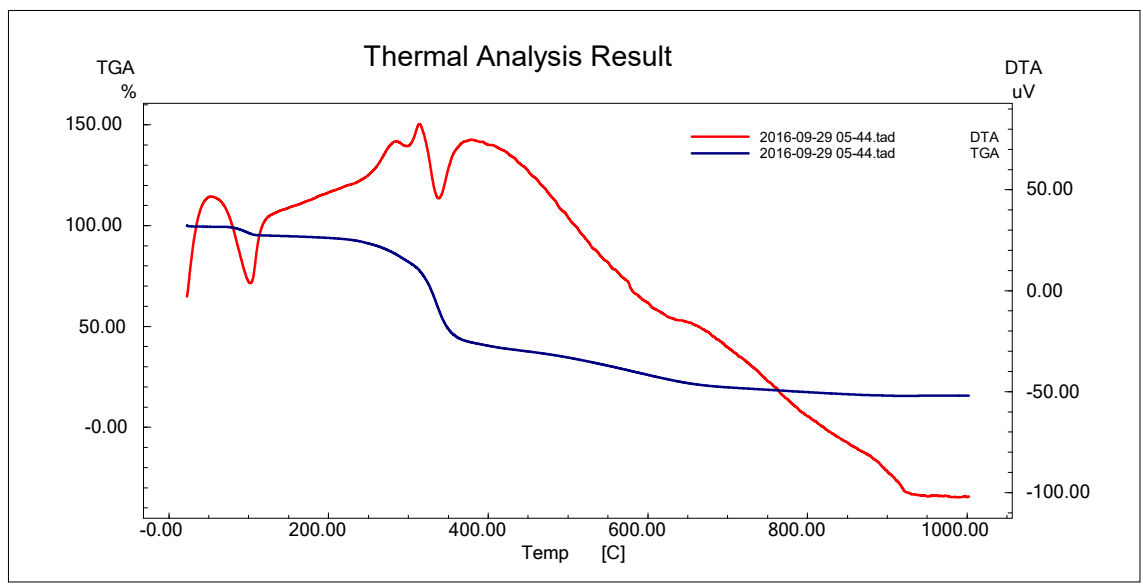

Figure 5. DTA/TG diagram of $\left[\mathrm{NiL}(\mathrm{phe})\left(\mathrm{H}_{2} \mathrm{O}\right)_{2}\right]$.

The Ni(II) complex (2), $\left[\mathrm{C}_{29} \mathrm{H}_{28} \mathrm{~N}_{3} \mathrm{O}_{6} \mathrm{BrNi}\right]$, is thermally decomposed in two successive decomposition steps within the temperature range $21-920{ }^{\circ} \mathrm{C}$. The first step with estimated mass loss of $6.12 \%$ was found within the temperature range $21-194{ }^{\circ} \mathrm{C}$ and corresponds to loss of two

Bull. Chem. Soc. Ethiop. 2020, 34(3) 
Synthesis and structural elucidation of some oxime-phenylalanine mixed ligand complexes 551

$\mathrm{H}_{2} \mathrm{O}$ molecules (calculated mass loss $=5.52 \%$ ). The second decomposition step of estimated mass loss $82.05 \%$ (calculated mass loss $=83.04 \%$ ) which is responsibly accounted for the decomposition of the ligand molecules with a final oxide residue of $\mathrm{NiO}$.

The $\mathrm{Cu}(\mathrm{II})$ complex (3), with the general formula $\left[\mathrm{C}_{29} \mathrm{H}_{28} \mathrm{~N}_{3} \mathrm{O}_{6} \mathrm{BrCu}\right]$, shows decomposition pattern of two stages. The first steps with estimated mass loss of $6.40 \%$, found within the temperature range $21-181{ }^{\circ} \mathrm{C}$. Corresponding to loss of two $\mathrm{H}_{2} \mathrm{O}$ molecules (calculated mass loss $=5.48 \%$ ). The second steps with estimated total mass loss of $81.20 \%$, found within the temperature range $181-910{ }^{\circ} \mathrm{C}$ corresponding to decomposition of the ligand molecules (calculated mass loss $=82.43 \%$ ) leaving $\mathrm{CuO}$ residue.

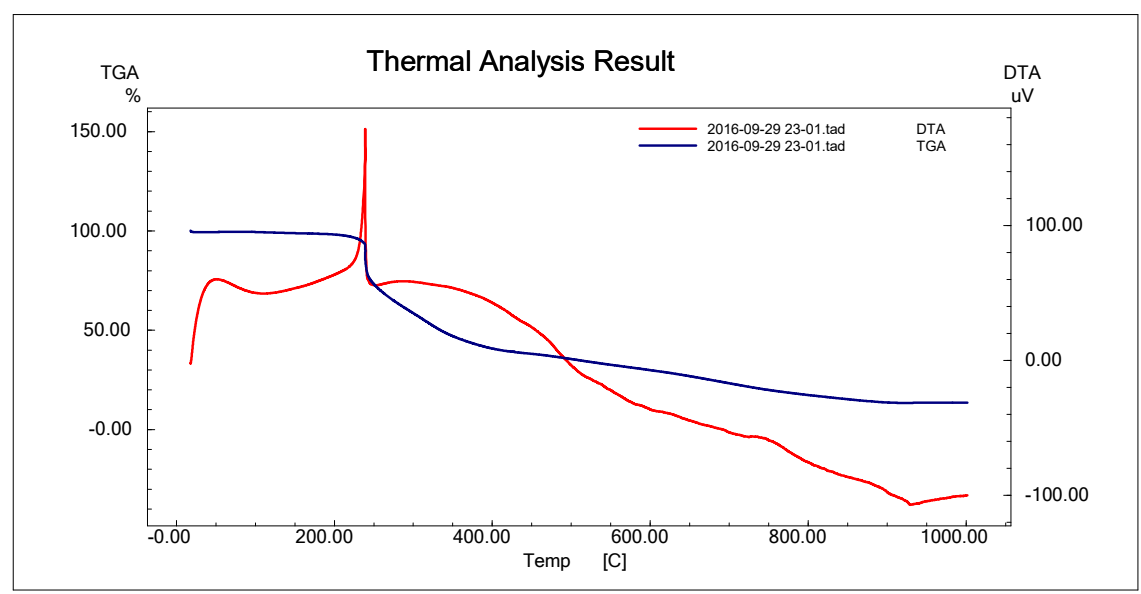

Figure 6. DTA/TG diagram of $\left[\mathrm{CuL}(\mathrm{phe})\left(\mathrm{H}_{2} \mathrm{O}\right)_{2}\right]$.

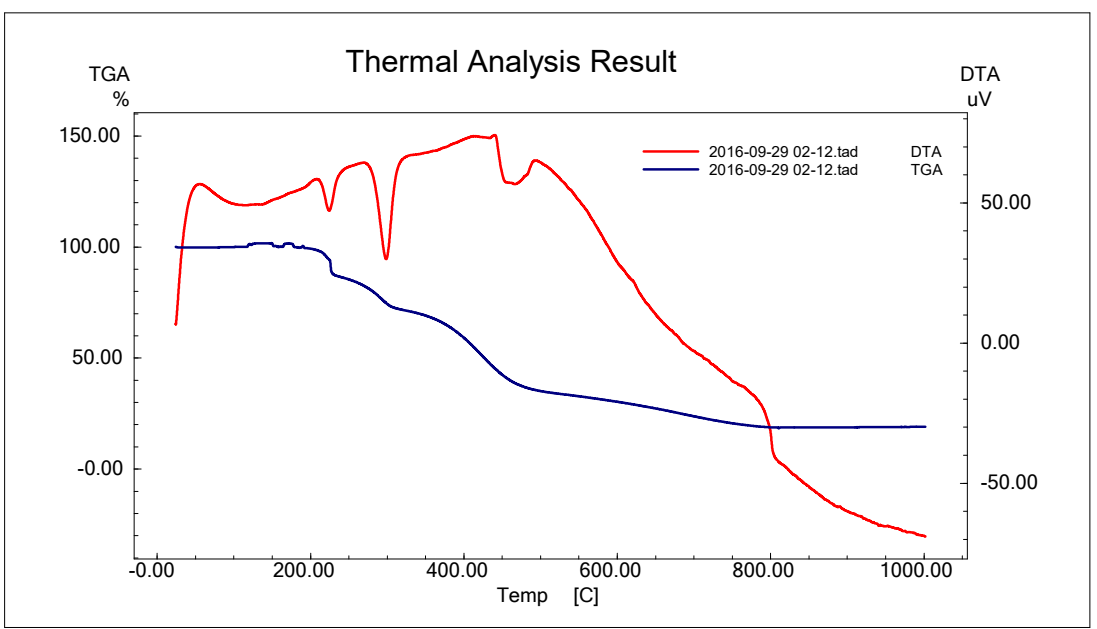

Figure 7. DTA/TG diagram of $\left[\mathrm{ZnL}(\mathrm{phe})\left(\mathrm{H}_{2} \mathrm{O}\right)_{2}\right]$.

The $\mathrm{Zn}(\mathrm{II})$ complex (4), with the general formula $\left[\mathrm{C}_{29} \mathrm{H}_{28} \mathrm{~N}_{3} \mathrm{O}_{6} \mathrm{BrZn}\right]$, also shows decomposition pattern of two stages. The first step with estimated mass loss of $5.90 \%$, found

Bull. Chem. Soc. Ethiop. 2020, 34(3) 
within the temperature range $21-238{ }^{\circ} \mathrm{C}$. Corresponding to loss of two $\mathrm{H}_{2} \mathrm{O}$ molecules (calculated mass loss $=5.46 \%$ ). The second step with anestimated total mass loss $81.63 \%$ which is due to loss of theligand molecules leaving $\mathrm{ZnO}$ residue occurring withinthe temperature range $238-840^{\circ} \mathrm{C}$ (calculated mass loss $=82.20 \%$ ).

\section{Cyclic voltammetry}

The application of electrochemical methods to study of the coordination of metal ion provides a helpful complement to the previously used methods of investigations such as spectroscopy. The electrochemical properties of ligands and their complexes were investigated by cyclic voltammetry. The potential was scanned in the range $-2.0 \mathrm{~V}$ to $+2.0 \mathrm{~V}$ at a scan rate $100 \mathrm{mVs}^{-1}$. The cyclic voltammogram of phenylalanine showed one anodic wave and one cathodic wave located at $+0.75 \mathrm{~V}$ and $-0.87 \mathrm{~V}$. In the voltammogram of HL, one anodic wave is observed at $+0.95 \mathrm{~V}$ which can be attributed to the oxidation of the oxime group [44]. The results of cyclic voltammetric investigations of all the complexes are summarized in Table 1 and the cyclic voltammogram of complex 2, HL and DMF are presented in Figure 8. The anodic wave seen around $+0.95 \mathrm{~V}$ in the CVs for all metal complexes are presumed to be ligand based oxidation. The voltammograms of the metal complexes, in addition to the ligands peak, also have oxidation and reduction peaks. The peaks of the complexes confirm the presence of metal cations and ligands in the complexes.

Table 1. Electrochemical data of the complexes ${ }^{\mathrm{a}}$.

\begin{tabular}{|c|c|c|c|}
\hline Complex & $E_{\mathrm{pa}}(\mathrm{V})$ & $E_{\mathrm{pc}}(\mathrm{V})$ & $\Delta E_{\mathrm{p}}(\mathrm{mV})$ \\
\hline $\mathbf{1}$ & - & -1.56 & - \\
\hline $\mathbf{2}$ & +1.35 & -1.65 & 300 \\
\hline $\mathbf{3}$ & -0.07 & -0.52 & 450 \\
\hline $\mathbf{4}$ & +0.21 & -0.09 & 120 \\
\hline
\end{tabular}

${ }^{\mathrm{a}}$ Supporting electrolyte, TBAP $(0.1 \mathrm{M})$ in DMF; Scan rate, $100 \mathrm{mVs}^{-1} ; \Delta E p=(E \mathrm{pa}-E \mathrm{pc})$, where $E \mathrm{pa}$ and $E \mathrm{pc}$ are anodic and cathodic potentials, respectively.

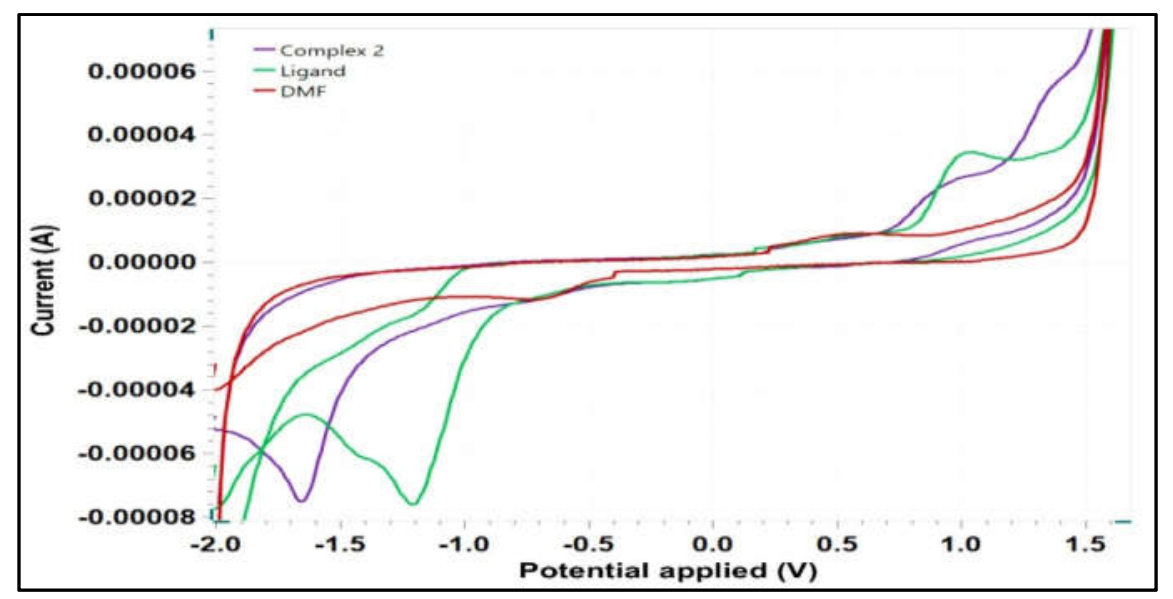

Figure 8. Cyclic voltammograms of complex 2, HL and DMF (0.1 M TBAP) at scan rate of 100 $\mathrm{mV} \mathrm{s}^{-1}$ versus $\mathrm{Ag} / \mathrm{Ag}+$ electrode. 
Through the analysis of the CV voltammograms obtained at various scanning speeds, the transfer of electrons and the way of transporting the substance to the electrode surface are known. The cyclic voltammetric behaviors of the ligand and complexes were studied by varying the sweep rate from $20 \mathrm{mVs}^{-1}$ to $500 \mathrm{mVs}^{-1}$. Linear correlations were obtained between square root of scan rate $\left(\mathrm{v}^{1 / 2}\right)$ and peak current $\left(\mathrm{I}_{\mathrm{pc}}\right.$ (Figure 9$)$. On the other hand, the slope values of the correct equations between the logarithm of the potential scanning speed (log $v)$ and the logarithm of the peak current $\left(\log I_{p c}\right)$ were found in values ranging from 0.75 to 1.0. These values confirmed that the process was adsorption controlled.

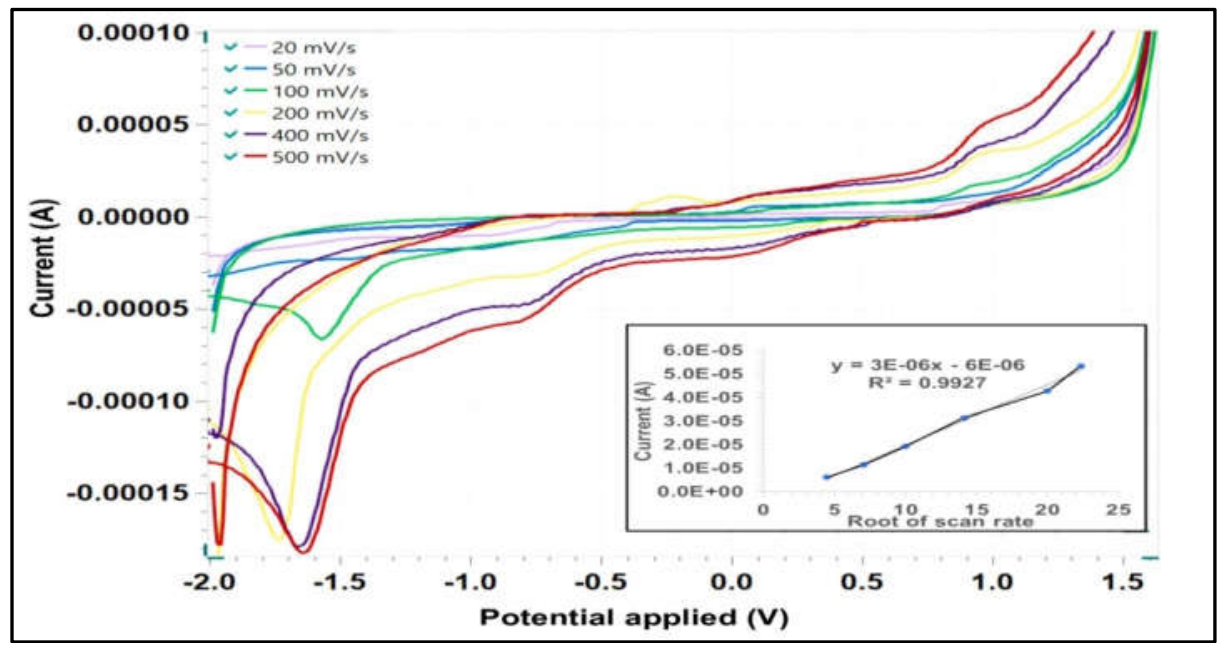

Figure 9. Cyclic voltammograms of complex 1 in DMF solution (0.1 M TBAP) at differentscan rates.

\section{CONCLUSION}

In conclusion, a new (4-(4-bromophenylaminoisonitrosoacetyl)biphenylligand (HL) and their mixed ligand $\mathrm{Co}(\mathrm{II}), \mathrm{Ni}(\mathrm{II}), \mathrm{Cu}(\mathrm{II})$ and $\mathrm{Zn}(\mathrm{II})$ complexes with L-phenylalanine were synthesized and were characterized by elemental analysis, magnetic susceptibility measurements, CV, FTIR, and ${ }^{1} \mathrm{H}$ NMR. Elemental analysis, stoichiometric and spectroscopic data of the metal complexes indicated that the complexes can be formulated as $\left[\mathrm{MeL}(\mathrm{phe})\left(\mathrm{H}_{2} \mathrm{O}\right)_{2}\right]$. The results obtained by $\mathrm{CV}$ method pointed out that the electrode reaction was adsorption controlled.

\section{REFERENCES}

1. Motaleb, M.A.; Selim, A.A. Dioximes: Synthesis and biomedical applications. Bioorg. Chem. 2019, 82, 145-155.

2. Das, O.; Adarsh, N.N.; Paul, A.; Paine,T.K. Copper(II) and nickel(II) complexes of $\beta$ aminoketoxime ligand: Syntheses, crystal structures, magnetism, and nickel(II) templated coupling of oxime with nitrile. Inorg. Chem. 2010, 49, 541-551.

3. Karipcin, F.; Arabali, F. Synthesis and characterization of new ketooximes and their complexes. Russ. J. Inorg. Chem. 2006, 51, 1467-1472. 
4. Dede, B.; Özmen, I.; Karipcin, F. Synthesis, characterization, catalase functions and DNA cleavage studies of new homo and heteronuclear Schiff base copper(II) complexes. Polyhedron 2009, 28, 3967-3974.

5. Ghasemi, J.B.; Zolfonoun, E. Simultaneous spectrophotometric determination of trace amounts of uranium, thorium, and zirconium using the partial least squares method after their preconcentration by alpha-benzoin oxime modified Amberlite XAD-2000 resin. Talanta 2010, 80, 1191-1197.

6. Nolvachai, Y.; Kulsing, C.; Trapp, O.; Marriott, P.J. Multidimensional gas chromatography investigation of concentration and temperature effects of oxime interconversion on ionic liquid and poly(ethylene glycol) stationary phases. Anal. Chim. Acta 2019, 1081, 200-208.

7. Bandyopadhyay, N.; Zhu, M.; Lu, L.; Mitra, D.; Das, M.; Das, P.; Samanta, A.; Naskar, J.P. Synthesis, structure, spectral characterization, electrochemistry and evaluation of antibacterial potentiality of a novel oxime-based palladium(II) compound. Eur. J. Med. Chem. 2015, 89, 59-66.

8. Bandyopadhyay, N.; Pradhan, A.B.; Das, S.; Lu, L.; Zhu, M.; Chowdhury, S.; Naskar, J.P. Synthesis, structure, DFT calculations, electrochemistry, fluorescence, DNA binding and molecular docking aspects of a novel oxime based ligand and its palladium(II) complex. $J$. Photochem. Photobiol. B 2016, 160, 336-346.

9. Sorensen, M.; Neilson, E.H.J.; Moller, B.L. Oximes: Unrecognized chameleons in general and specialized plant metabolism. Mol. Plant 2018, 11, 95-117.

10. Canaj, A.B.; Kakaroni, F.E.; Collet, A.; Milios, C.J. $\alpha$-Amino acids: Natural and artificial building blocks for discrete polymetallic clusters. Polyhedron 2018, 151, 1-32.

11. Bougherra, H.; Berradj, O.; Adkhis, A.; Amrouche, T. Synthesis, characterization, electrochemical and biological activities of mixed ligand copper(II) complexes with dimethylglyoxime and amino acids. J. Mol. Struct. 2018, 1173, 280-290.

12. Rahmouni, N.T.; Bensiradj, N.H.; Megatli, S.A.; Djebbar, S.; Baitich, O.B. New mixed amino acids complexes of iron(III) and zinc(II) with isonitrosoacetophenone: Synthesis, spectral characterization, DFT study and anticancer activity. Spectrochim. Acta Part A 2019, 213, 235-248.

13. Alvarez, S. Coordinating ability of anions, solvents, amino acids, and gases towards alkaline and alkaline-earth elements, transition metals, and lanthanides. Chem. Eur. J. 2020, 26, 4350-4377.

14. Annaraj, B.; Balakrishnan, C.; Neelakantan, M.A. Synthesis, structure information, DNA/BSA binding affinity and in vitrocytotoxic studies of mixed ligand copper(II) complexes containing a phenylalanine derivative and diimine co-ligands. J. Photochem. Photobiol. B 2016, 160, 278-291.

15. Zobi, F.; Spingler, B.; Alberto, R. Guanine and plasmid DNA binding of mono- and trinuclear $f a c$ - $\left[\mathrm{Re}(\mathrm{CO})_{3}\right]^{+}$complexes with amino acid ligands. ChemBioChem 2005, 6, 1397 1405.

16. Li, A.; Liu, Y.H.; Yuan, L.Z.; Ma, Z.Y.; Zhao, C.L.; Xie, C.Z.; Bao, W.G.; Xu, J.Y. Association of structural modifications with bioactivity in three new copper(II) complexes of Schiff base ligands derived from 5-chlorosalicylaldehyde and amino acids. J. Inorg. Biochem. 2015, 146, 52-60.

17. Shobana, S.; Subramaniam, P.; Mitu, L.; Dharmaraja, J.; Narayan, S.A. Synthesis, structural elucidation, biological, antioxidant and nuclease activities of some 5-fluorouracil-amino acid mixed ligand complexes. Spectrochim. Acta Part A 2015, 134, 333-344.

18. Kumar, R.S.; Arunachalam, S. DNA binding and antimicrobial studies of polymercopper(II) complexes containing 1,10-phenanthroline and L-phenylalanine ligands. Eur. $J$. Med. Chem. 2009, 44, 1878-1883. 
19. Soayed, A.A.; Refaat, H.M.; El-Din, D.A.N. Metal complexes of moxifloxacin-imidazole mixed ligands: Characterization and biological studies. Inorg. Chim. Acta 2013, 406, 230240.

20. Mo, Q.Y.; Deng, J.G.; Liu, Y.; Huang, G.D.; Li, Z.W.; Yu, P.; Gou, Y.; Yang, F. Mixedligand $\mathrm{Cu}(\mathrm{II})$ hydrazone complexes designed to enhance anticancer activity. Eur. J. Med. Chem. 2018, 156, 368-380.

21. Roy, S.; Mondal, T.; Layek, K.A.; Saha, R.; Sinha, C. Structure, spectra and electrical conductivity of copper(I) and silver(I) phosphino bridging mixed ligand complexes with coumarinyl Schiff base. Inorg. Chim. Acta 2018, 469, 523-535.

22. Sugimoto, S.; Ohtsu, H.; Tsuge, K. Luminescent mixed-ligand iodido copper(I) coordination polymers having antenna effect. J. Photochem. Photobiol. A2018, 353, 602-611.

23. Tidjani-Rahmouni, N.; Bensiradj, N.H.; Djebbar, S.; Benali-Baitich, O. Synthesis, characterization, electrochemical studies and DFT calculations of amino acids ternary complexes of copper(II) with isonitrosoacetophenone: Biological activities. J. Mol. Struct. 2014, 1075, 254-263.

24. Gup, R.; Gökçe, C.; Dilek, N. Synthesis, structural characterization and DNA interaction of zinc complex from 2,6-diacetylpyridine dihydrazone and \{4-[(2E)-2-(hydroxyimino)acetyl]phenoxy $\}$ acetic acid. J. Photochem. Photobiol. B 2015, 144, 42-50.

25. Prushan, M.J.; Addison, A.W.; Butcher, R.J.; Thompson, L.K. Copper(II) complexes of tetradentate thioether-oxime ligands. Inorg. Chim. Acta 2005, 358, 3449-3456.

26. Mahmoud, W.H.; Mohamed, G.G.; El-Dessouky, M.M.I. Synthesis, structural characterization, in vitro antimicrobial and anticancer activity studies of ternary metal complexes containing glycine amino acid and the anti-inflammatory drug lornoxicam. $J$. Mol. Struct. 2015, 1082, 12-22.

27. Tas, E.; Aslanoglu, M.; Guler, M.; Ulusoy, M. Synthesis, characterization and electrochemical properties of copper(II) complexes with novel bidentate salicylaldimines derived from 3,5-di-t-butyl-2-hydroxybenzaldehyde. J. Coord. Chem. 2004, 57, 583-589.

28. Abdel-Rahman, L.H.; El-Khatib, R.M.; Nassr, L.A.E.; Abu-Dief, A.M. DNA binding ability mode, spectroscopic studies, hydrophobicity, and in vitro antibacterial evaluation of some new Fe(II) complexes bearing ONO donors amino acid Schiff bases. Arabian J. Chem. 2017, 10, S1835-S1846.

29. Bellamy, L.J. The Infrared Spectra of Complex Molecules, Advances in Infrared Group Frequencies, Chapman and Hall: Methuen, London; 1980.

30. Dharmaraja, J.; Balamurugan, J.; Shobana, S. Synthesis, structural elucidation, microbial, antioxidant and nuclease activities of some novel divalent M(II) complexes derived from 5fluorouracil and L-tyrosine. J. Saudi Chem. Soc. 2017, 21, S67-S76.

31. Begum, M.S.A.; Saha, S.; Nethaji, M.; Chakravarty, A.R. Iron(III) Schiff base complexes of arginine and lysine as netropsin mimics showing AT-selective DNA binding and photonuclease activity. J. Inorg. Biochem. 2010, 104, 477-484.

32. Dede, B.; Özmen, İ.; Karipcin, F.; Cengiz, M. Homo- and heteropolynuclear copper(II) complexes containing a new diimine-dioxime ligand and 1,10-phenanthroline: Synthesis, characterization, solvent-extraction studies, catalase-like functions and DNA cleavage abilities. Appl. Organometal. Chem. 2009, 23, 512-519.

33. Karipcin, F.; Uçan, H.İ.; Karataş, I. Binuclear and mononuclear cobalt(II), nickel(II) and copper(II) complexes of 4,4'-bis(alkylaminoisonitrosoacetyl)-diphenylmethane derivatives. Transition Met. Chem. 2002, 27, 813-817.

34. Dede, B.; Karipcin, F.; Arabal1, F.; Cengiz, M. Synthesis, structure, and solvent-extraction properties of tridentate oxime ligands and their cobalt(II), nickel(II), copper(II), zinc(II) complexes. Chem. Pap. 2010, 64, 25-33. 
35. Borah, M.M.; Devi, T.G. The vibrational spectroscopic studies and molecular property analysis of L-phenylalanine using quantum chemical method. J. Mol. Struct. 2017, 1136, 182-195.

36. Mamun, M.A.; Ahmed, O.; Bakshi, P.K.; Ehsan, M.Q. Synthesis and spectroscopic, magnetic and cyclic voltammetric characterization of some metal complexes of methionine: $\left[\left(\mathrm{C}_{5} \mathrm{H}_{10} \mathrm{NO}_{2} \mathrm{~S}\right)_{2} \mathrm{M}^{\mathrm{II}}\right] ; \mathrm{M}^{\mathrm{II}}=\mathrm{Mn}(\mathrm{II}), \mathrm{Co}(\mathrm{II}), \mathrm{Ni}(\mathrm{II}), \mathrm{Cu}(\mathrm{II}), \mathrm{Zn}(\mathrm{II}), \mathrm{Cd}(\mathrm{II})$ and $\mathrm{Hg}(\mathrm{II}) . J$. Saudi Chem. Soc. 2010, 14, 23-31.

37. Cotton, F.A.; Wilkinson, G.; Murillo, C.A.; Bochmann, M. Advanced Inorganic Chemistry, 6th ed., Wiley-Interscience: New York; 1999.

38. Khan, R.; Tavman, A.; Gürbüz, D.; Arfan, M.; Çinarli, A. Synthesis and structural characterization of $\mathrm{N}-(2-\{[(2 \mathrm{E})-2-(2-H y d r o x y b e n z y l i d e n e) h y d r a z i n y l]$ carbonyl $\}$ phenyl)benzamide (HL) and its $\mathrm{Co}(\mathrm{II}), \mathrm{Fe}(\mathrm{III}), \mathrm{Cu}(\mathrm{II})$ and $\mathrm{Zn}(\mathrm{II})$ complexes: X-ray crystal structure of HL. Bull. Chem. Soc. Ethiop. 2018, 32, 111-124.

39. Brown, V. Introduction to Thermal Analysis, Kluwer Academic Publisher: London; 2001.

40. Duval, C. Inorganic Thermogravimetric Analysis, 2nd ed., Elsevier: Amsterdam; 1963.

41. Dholariya, H.R.; Patel, K.S.; Patel, J.C.; Patel, K.D. Dicoumarol complexes of Cu(II) based on 1,10-phenanthroline: synthesis, X-ray diffraction studies, thermal behavior and biological evaluation. Spectrochim. Acta Part A 2013, 108, 319-328.

42. Ikram, M.; Rehman, S.; Khan, A.; Baker, R.J.; Hofer, T.S.; Subhan, F.; Qayum, M.; Schulzke, C. Synthesis, characterization, antioxidant and selective xanthineoxidase inhibitory studies of transition metal complexes of novel amino acidbearing Schiff base ligand. Inorg. Chim. Acta 2015, 428, 117-126.

43. Hossain, M.A.; Low, C.Y.L.; Sheikh, C.M.; Juan, J.C.; Lee, H.V. Synthesis, X-ray diffraction studies, thermal behavior and catalytic investigation of $\mathrm{Cu}$ (II) complexes for levulinic acid-based polyol esters. J. Mol. Struct. 2019, 1175, 566-576.

44. Abane-Merzouk, L.; Adkhis, A.; Terrachet-Bouaziz, S.; Makhloufi-Chebli, M. Synthesis, DFT/TD-DFT theoretical studies, experimental characterization, electrochemical and antioxidant activity of Fe(II) complexes of bis(dimethylglyoximato)guanine. J. Mol. Struct. 2019, 1186, 413-422. 